\title{
Water Use Efficiency of the First Ratoon Cane by Eddy Covariance Technique
}

\author{
Tiwa Pakoktom, Nongpat Chaichana, Jessada Phattaralerphong, and Jate Sathornkich
}

\begin{abstract}
The propose of this study is to evaluate water use of the first ratoon cane. First ratoon cane was produced at Cane and Sugar Industry Promotion Center Region 1 from June 2010 to April 2011. To evaluate crop water use Eddy Covariance technique was used. From the results, water use of first ratoon cane was gradually increased from predawn and reach the maximum during 12:00-14:00 and then water use was decreased. Moreover, water use in each growing stage were found. Minimum of water use average about $1.6 \mathrm{mmd}^{-1}$ was found in germination stage, while maximum water use is 2.4 $\mathrm{mmd}^{-1}$ was found in stalk elongation stage. In addition, total water use germination stage, tillerling stage, stalk elongation stage and maturity stage was $57.3,151.3,330.6$ and $142.7 \mathrm{~mm}$, respectively. However, total water use of first ratoon cane was $682.1 \mathrm{~mm}$. Water Use Efficiency of $1^{\text {st }}$ ratoon cane was 0.012 tyield/th $\mathrm{H}_{2} \mathrm{O}$. For this study we can concluded that water use of first ratoon cane depend on daily time and growing stage and total water use was $682.1 \mathrm{~mm}$.
\end{abstract}

Index Terms-Eddy covariance technique, first ratoon cane, water use efficiency.

\section{INTRODUCTION}

Sugarcane is an important crop in Thailand and global not only for sugar production but also increasingly as a bioenergy crop due to its phenomenal dry matter production capacity [1]. Sugarcane global production now estimated at 1,250 million tons a year, the production yield of sugarcane in Thailand is about 106 million tons per year. Total planting area of sugarcane in Thailand is 1.42 million ha rely on irrigation to a small extent $(20 \%)$ to produce a viable crop [2]. Seasonal water requirements for sugarcane have been derived mostly from a relationship between cane yield and water used through transpiration and soil evaporation [3]. Water flux and water use can be measured using many methods and Eddy Covariance technique (EC) is the new method which do not interfere with process of gas exchange between the surface source and the atmosphere [4]. This technique has been used to measure $\mathrm{H}_{2} \mathrm{O}$ flux and many studies have been published [5]. However, most of water exchange studies involved short-term measurements. In this paper, we present seasonal variation of $\mathrm{H}_{2} \mathrm{O}$ flux at a customarily cultivated single

Manuscript received March 5, 2013; revised May 6, 2013. This work was supported in part by the Office of the Cane and Sugar Board, Thailand.

T. Pakoktom and N. Chaichana are with the Department of Agronomy, Faculty of Agriculture at Kamphaeng Saen, Kasetsart University, Kamphaeng Saen Campus, Thailand (e-mail: agrtwp@ku.ac.th, nongpat.chai@gmail.com).

J. Phattaralerphong is with the Faculty of Natural Resource and Agro-Indrustry, Kasetsart University, Chalermprakiat Sakon Nakorn, Thailand (e-mail: csnjdp@ku.ac.th).

J. Sathornkich is with the Department of Horticulture, Faculty of Agriculture Kasetsart University, Bangkok, Thailand (e-mail: psdjate@ku.ac.th). cropping sugarcane crop base on the results of a single season-long measurement of $\mathrm{H}_{2} \mathrm{O}$ flux using the EC technique.

\section{MATERIAL AND METHODS}

\section{A. Site Description and Period of Measurement}

This site was conducted at the first ratoon cane which is locates at Cane and Sugar Industry Promotion Center, Kanchanaburi province in Western Thailand. The site is located at $14.03^{\circ} \mathrm{E}$ latitude and $99.68^{\circ} \mathrm{N}$ longitude with an elevation of $22.37 \mathrm{~m}$ above sea level as shown in Fig. 1. The soil of the sugarcane field are sand and sandy loam. $\mathrm{A} \mathrm{H}_{2} \mathrm{O}$ flux measurement and meteorological tower is $6.0 \mathrm{~m}$ height and was erected in the center of plot area. The sugarcane fields around the tower were managed as single sugarcane-cropping fields following by a common management in this area. In this study, the data of the $1^{\text {st }}$ ratoon cane growing season (9 June 2010-31 April 2011) were analyzed.

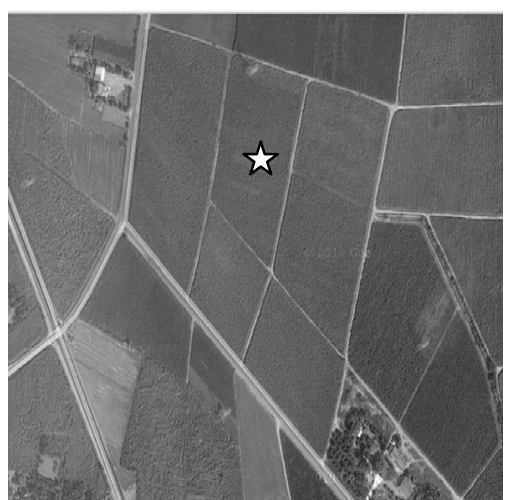

Fig. 1. The aerial photograph of experimental site and the star is the location of the EC tower.

\section{B. Meteorological Data Measurement}

The meteorological parameter consisted of solar radiation (Rs), net radiation $(\mathrm{Rn})$, total amount of rain, wind speed and wind direction, air temperature and relative humidity. All of meteorological instruments were installed on the tower at a height of $6.0 \mathrm{~m}$. The meteorological data were conducted and average in every 30 minute and stored in data logger CR1000 (Campbell Scientific, Inc.).

\section{Plant Growth}

Plant cane was planted in 30 June 2009 and the first ratoon cane starting from 9 June 2010. Growth characteristics which consisted of plant height, diameter, fresh and dry weight, leaf area (LA) and leaf area index (LAI). The samples were taken from 5 plots around the tower at monthly intervals 
commencing from 60 days after planted cane was harvested until the next harvest. Each samples consisted of the above-ground portions of all shoots, the shoots were separated into stem, leaf blade and leaf sheath. When the amount of sample was in excess, a portion of representative subsample was used for dry weight determination, extrapolated for a whole sample, which was designated as the total dry matter. All samples were oven dried at $80^{\circ} \mathrm{C}$ until a constant weight was reached. Sugarcane growing stage separated by four different growth stage, comprising germination and emergence, tillering and canopy establishment, grand growth, and maturation which are 1, 2, 7 and 2 months in length, respectively [6].

\section{Eddy Covariance Flux Measurement}

$\mathrm{H}_{2} \mathrm{O}$ flux was measured by the Eddy Covariance technique. Three components of wind velocity and temperature fluctuation were measured with a sonic anemometer (CSAT-3; LI-COR, Inc., Lincoln, NE, USA). The density of $\mathrm{H}_{2} \mathrm{O}$ was measured with an open-path infrared gas analyzer (IRGA) (LI-7500; LI-COR, Inc., Lincoln, NE, USA). The sensor heads of the sonic anemometer and IRGA were mounted the tower at a height of $2.0 \mathrm{~m}$. above the plant canopy. The data from the sonic anemometer and IRGA were sample at $20 \mathrm{~Hz}$ using a 16-bit digital data recorder and stored in data logger CR3000. Half-hourly flux density of the $\mathrm{H}_{2} \mathrm{O}$ was calculated from the covariance between the vertical wind velocity and the respective quantities. All data were downloaded to computer every week and the quality check by using the standard meteorology [7].

\section{E. Water Use Efficiency (WUE)}

Water use efficiency has become the relationship between the crop growth development and the amount of water use. And referring to the ratio between the biomass or yield and crop transpiration [8]. Moreover, recently global warming has been the hot issue, and needed urgent countermeasures because global warming would increase water consumption [9].

In this study, evaluate water use efficiency (WUE) of the $1^{\text {st }}$ ratoon cane was calculated as follow equation [10].

$$
\begin{aligned}
& \text { Water use } \\
& \text { efficiency }
\end{aligned} \quad=\frac{\text { Grain yield (tyield) }}{\text { Crop water use }\left(\mathrm{tH}_{2} \mathrm{O}\right)}
$$

where crop water use was determined from $\mathrm{H}_{2} \mathrm{O}$ flux as estimated using Eddy Covariance Technique.

\section{RESULTS}

\section{A. Meteorological Data}

Meteorological condition in the first ratoon cane during 9 June 2010-30 April 2011 are shown in Fig. 2. Daily average solar radiation (Rs) variation ranged from 3.29-27.56 $\mathrm{MJm}^{-2} \mathrm{~d}^{-1}$, lower levels of solar radiation in March 2011. Net radiation $(\mathrm{Rn})$ was increased after the sunrise and reached its maximum at noon. The daily average of $\mathrm{Rn}$ variation ranged from 0.63-398 $\mathrm{Wm}^{-2}$. The trend of average air temperature (Ta) and average of relative humidity $(\mathrm{RH})$ as shown in Fig. 3 The Ta fluctuation was between $17.9-31.1^{\circ} \mathrm{C}$, its minimum was $17.9^{\circ} \mathrm{C}$ in March 2011 and its maximum was $31.1^{\circ} \mathrm{C}$ in April 2011. The average of relative humidity ( $\mathrm{RH}$ ) was $71 \%$ its minimum was $53 \%$. Total amount of rain during the study period was $345 \mathrm{~mm}$ and its maximum was $61.1 \mathrm{~mm}$ per day which was occurred in 29 June 2010 (Fig. 4).

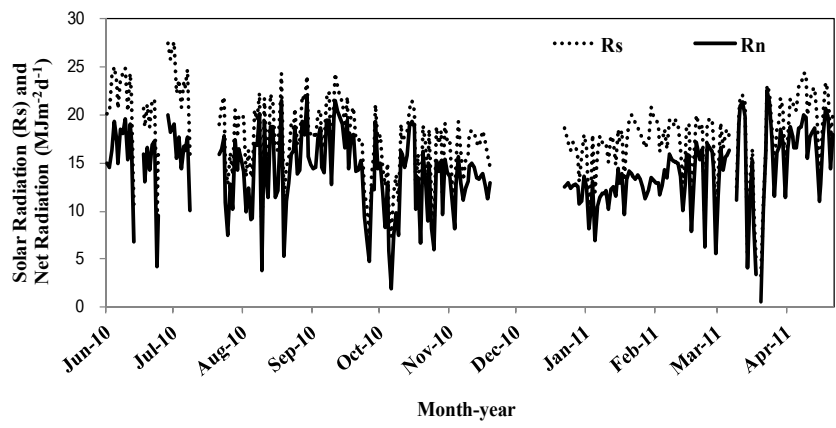

Fig. 2. Time series of solar radiation (Rs) and net radiation (Rn) at the experimental site from 9 June 2010-30 April 2011.

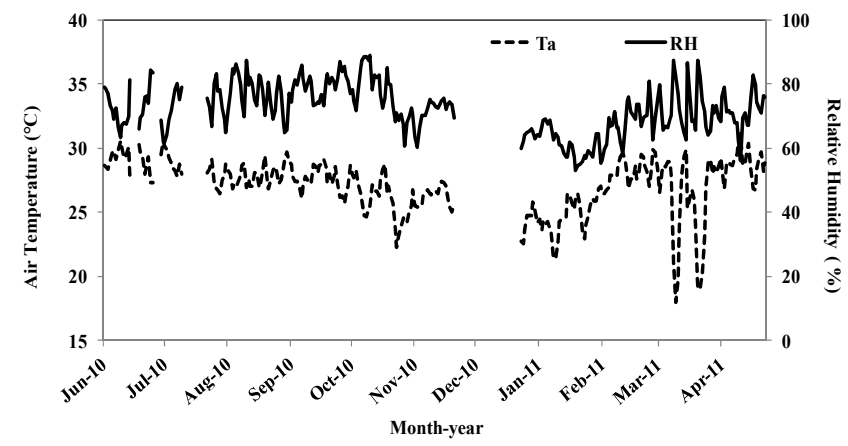

Fig. 3. Time series of average air temperature (Ta) and average relative humidity (RH) at the experimental site from 9 June 2010-30 April 2011.

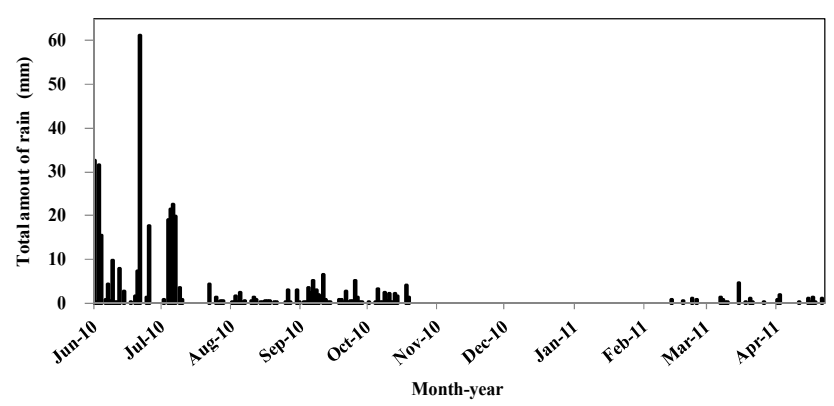

Fig. 4. Total amount of rain at the experimental site during 9 from 2010-30 April 2011.

\section{B. Plant Growth Parameter}

Plant height was increased gradually from starting the measurement and reached to the saturated point at $210 \mathrm{DAH}$. Plant height was reached a maximum of $268.7 \mathrm{~cm}$ in maturity stage as show in Fig. 5 (a). The LAI shown a gradually increase from the tillering stage and reached a maximum at stalk elongation stage (Fig. 5(b)).

\section{Daily Trend of $\mathrm{CO}_{2}$ Flux}

All of the data set of the first ratoon cane were analyzed for the daily trend of $\mathrm{H}_{2} \mathrm{O}$ flux. The daily trend of $\mathrm{H}_{2} \mathrm{O}$ flux is presented in Fig. 6. Throughout the measurement period, the daily values ranged from 0.0008 to $0.0736 \mathrm{gH}_{2} \mathrm{Om}^{-2} \mathrm{~s}^{-1}$. The fluxes of $\mathrm{H}_{2} \mathrm{O}$ were smaller during the nighttime and started 
increasing at 7:00 and continued onwards, the conductance increased continuously up noon, and steadily declined thereafter.

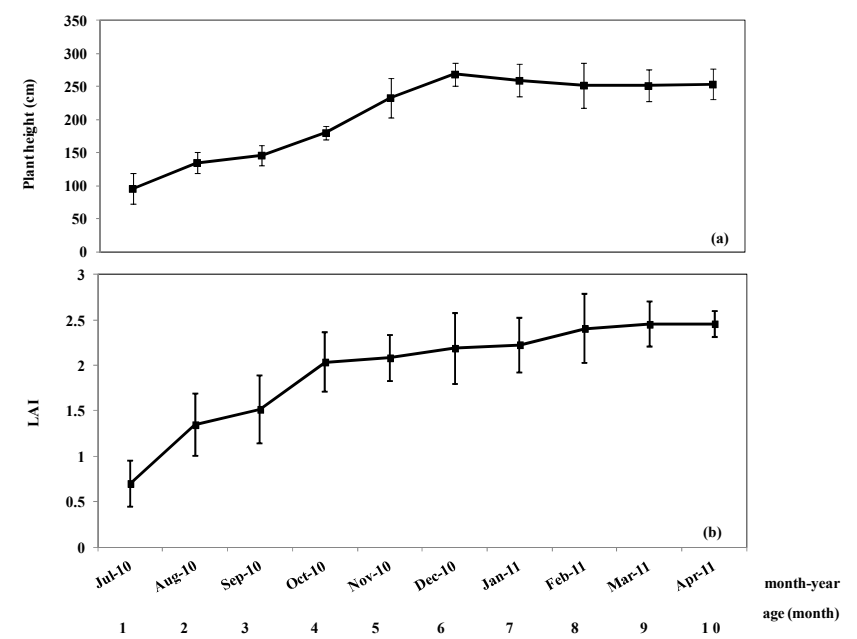

Fig..5. The plant height $(\mathrm{cm})$ and leaf area index (LAI) of the first ratoon cane.

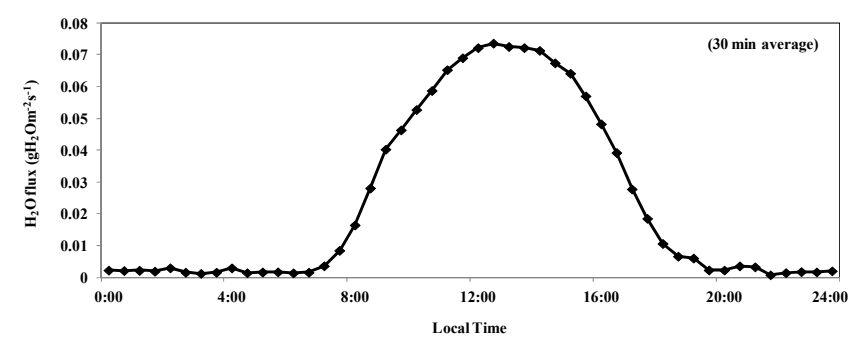

Fig. 6. Daily trend of $\mathrm{H}_{2} \mathrm{O}$ flux of the first ratoon cane from 9 June 2010-30 April 2011.

\section{Daily Trend of $\mathrm{H}_{2} \mathrm{O}$ Flux in Each Growing Stage}

In each growing stage daily trend of $\mathrm{H}_{2} \mathrm{O}$ flux was similar, On the other hand, this variance of $\mathrm{H}_{2} \mathrm{O}$ flux in each growing stage. In germination, tillering, grand growth and maturation the variation range between 3.67 to $167.99,-8.87$ to 213.69 , 2.07 to 192.01 and -0.45 to $139.01 \mathrm{gH}_{2} \mathrm{Om}^{-2} \mathrm{~s}^{-1}$, respectively (Fig. 7).

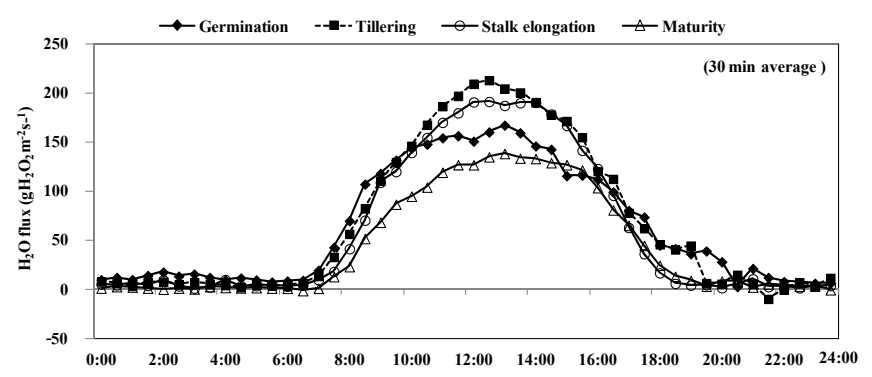

Fig. 7. Daily trend of $\mathrm{H}_{2} \mathrm{O}$ flux in each growing stage of the first ratoon cane from 9 June 2010-30 April 2011.

\section{E. Seasonal Trend of $\mathrm{H}_{2} \mathrm{O}$ Flux}

Seasonal variation of $\mathrm{H}_{2} \mathrm{O}$ flux as shown in Fig. 8. The daily values ranged fluctuation between 0.7 to $4.3 \mathrm{mmd}^{-1}$. The average and total of water use in each growing stage as shown in Table 1. Total of water use in germination stage, tillering stage, stalk elongation stage and maturity stage were $57.3,151.3,330.6$ and $142.7 \mathrm{~mm}$, respectively. Total of water use of the $1^{\text {st }}$ ratoon cane were $682.1 \mathrm{~mm}$.

\section{F. Water Use Efficiency of the $1^{\text {st }}$ Ratoon Cane}

Throughout the $1^{\text {st }}$ ratoon cane growing season, sugarcane biomass was 83.75 ton/hectare. And the $1^{\text {st }}$ ratoon cane field can be absorbed $\mathrm{CO}_{2} 4,300.4 \mathrm{gCO}_{2} \mathrm{~m}^{-2}$. Carbon use efficiency on the $1^{\text {st }}$ ratoon cane was $2.13 \mathrm{tCO}_{2} /$ tyield.

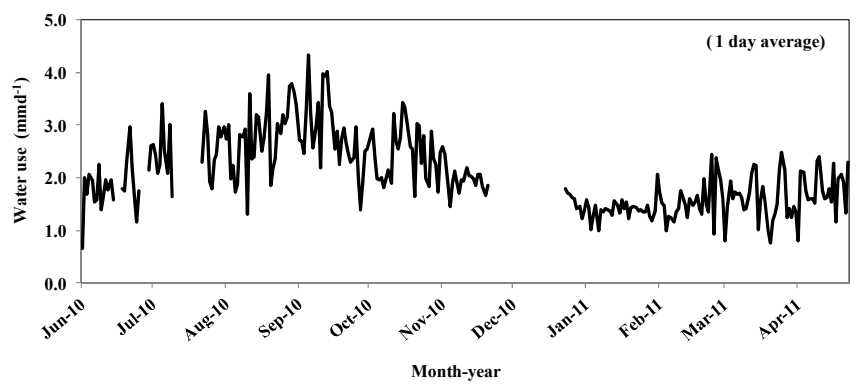

Fig. 8. Seasonal trend of $\mathrm{H}_{2} \mathrm{O}$ flux of the first ratoon cane from 9 June 2010-30 April 2011.

TABLE I: THE AVERAGE AND TOTAL OF WATER USE IN EACH GROWING STAGE OF THE FIRST RATOON CANE

\begin{tabular}{|c|c|c|c|c|}
\hline $\begin{array}{l}\text { Month } \\
\text { Year }\end{array}$ & $\begin{array}{c}\text { Month after } \\
\text { plant cane } \\
\text { harvesting }\end{array}$ & $\begin{array}{l}\text { Growing } \\
\text { stage }\end{array}$ & $\begin{array}{c}\begin{array}{c}\text { Average of } \\
\text { water use } \\
\left(\mathrm{mmd}^{-1}\right)\end{array} \\
\end{array}$ & $\begin{array}{c}\text { Total of } \\
\text { water use } \\
(\mathrm{mm})\end{array}$ \\
\hline Jun 2010 & 2 & Germination & 1.9 & 57.3 \\
\hline $\begin{array}{c}\text { July-Aug } \\
2010\end{array}$ & $3-4$ & Tillering & 2.4 & 151.3 \\
\hline $\begin{array}{l}\text { Sep 2010- } \\
\text { Jan } 2011\end{array}$ & $5-7$ & $\begin{array}{c}\text { Stalk } \\
\text { elongation }\end{array}$ & 2.2 & 330.6 \\
\hline $\begin{array}{c}\text { Feb-Apr } \\
2011\end{array}$ & $8-11$ & Maturity & 1.0 & 142.7 \\
\hline Total & 11 & & 2.0 & 682.1 \\
\hline
\end{tabular}

\section{Discussions}

During transpiration, energy gradients develop along the transpiration pathway. This is necessary for water to flow from the roots, through the xylem to the leaves. Reference [11] shows the water use of rice paddy field varied in each growing stage and highest water use achieved when rice has a high leaf area index or that is high leaf density. In a previous study on sugarcane in Thailand [12], water use was increased gradually from after planting and reached to the saturated point at 4 month after planting and totally of water use of plant cane (7 months) was $682.1 \mathrm{~mm}$.

\section{CONCLUSION}

The fluxes of $\mathrm{H}_{2} \mathrm{O}$ were smaller during the nighttime and then started increasing from 7:00 a.m. and continued onwards, the conductance increased continuously up noon, and steadily declined thereafter, caused from plants transpire in photosynthesis system. $\mathrm{H}_{2} \mathrm{O}$ flux each growing stage were difference and water use in germination stage, tillering stage, stalk elongation stage and maturity stage was 57.3, 151.3, 330.6 and $142.9 \mathrm{~mm}$, respectively. All season, the water use of the first ratoon cane was $682.1 \mathrm{~mm}$. And water use efficiency of the $1^{\text {st }}$ ratoon cane was 0.012 tyield $/ \mathrm{tH}_{2} \mathrm{O}$.

\section{ACKNOWLEDGMENT}

This study was financially supported by the Office of the Cane and Sugar Board and Thai Research Found (TRF). 
Many thanks to Center of Thai-French Cooperation on Higher Education and Research (DORAS center) for their encouragement and field instrumentations. Finally, we are grateful to the Cane and Sugar Industry Promotion Center for providing the experimental plots and field assistance.

\section{REFERENCES}

[1] A. S. Marcelo, J. L. Jifon, J. A. G. Da Silva, and V. Sharma, "Use of physiological parameters as fast tools to screen for drought tolerance in sugarcane," Braz. J. Plant Physiol., vol. 19, no. 3, pp. 193-201, 2007.

[2] Office of the Cane and Sugar Board. (September 2012). Report on Cane and Sugar Production 2011/12. [Online]. Available: http://www.ocsb.go.th/upload/journal/fileupload/923-3963.pdf.

[3] N. G. Inman-Bamber and D. M. Smith, "Water relations in sugarcane and response to water deficits," Field Crop Research, vol. 92 pp. $185-202,2005$

[4] T. Kuo-Hsin, J. Tsai, A. Alagesan, B. Tsuang, M. Yao, and P. Kuo, "Determination of methane and carbondioxide fluxes during the rice maturity period in Taiwan by combining profile and eddy covariance measurements," Agricultural and Forest Meteorology, vol. 150, pp. $825-859.2010$

[5] A. P. Schrier-Uijl, P. S. Kroon, A. Hensen, P. A. Leffelaar, F. Berendse, and E. M. Veenendaal, "Comparision of chamber and eddy covariance-based $\mathrm{CO}_{2}$ and $\mathrm{CH}_{4}$ emission estimates in a heterogeneous grass ecosystem on peat," Agricultural and Forest Meteorology, vol. 150 , pp. 825-831, 2010.

[6] G. J. Gascho, "Water-sugarcane relationship," Sugar Journal, vol. 48, no. 6 , pp. 11-17, 1985

[7] S. Makoto, A. Miyata, H. Nagai, and T. Yamada, "Seasonal variation of carbon dioxide exchange in rice paddy field in Japan," Agricultural and Forest Meteorology, vol. 135, pp. 93-109, 2005.

[8] L. Nicola, S. Muhammad, T. Mladen, B. Claudio and A. Rossella, "Water Use Efficiency and Water Productivity," Present at the Proceeding of $4^{\text {th }}$ WASAMED Workshop, Amman, Jordan, 30 Sept -4 Oct, 2005.

[9] T. Pakoktom, "Evaluation of Evapotranspiration in Paddy Rice Fields Using $\mathrm{CO}_{2}$ and $\mathrm{H}_{2} \mathrm{O}$ Fluxes Ratio," Ph.D. Thesis, United Graduate School of Agriculture Science, Tokyo University of Agriculture and Technology, Japan, 2009.

[10] A. K. Bhardwaj, T. Zenone, P. Jasrotia, G. P. Robertson, J. Chen, and K. Hamilton, "Water and energy footprints of bioenergy crop production on mariginal lands," GCB Bioenergy, vol. 3, pp. 208-222, 2011.

[11] T. Pakoktom, M. Aoki, P. Kasemsap, S. Boonyawat, and P. Attarod, " $\mathrm{CO}_{2}$ and $\mathrm{H}_{2} \mathrm{O}$ fluxes ratio in paddy fields of Thailand and Japan," Hydrological Research Letter, vol. 3, pp. 10-13, 2009.

[12] P. Jessada, K. Poonpipope, T. Sornprach, and S. Duangrat, "Study on water use of sugarcane," Final report on Project to Create Knowledge and Develop Sugarcane Year, Nakhon Pathom, Thailand, pp. 53-57, 2008.

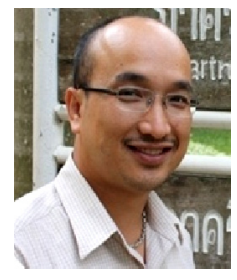

Tiwa Pakoktom was born in Thailand. He was awarded his Bachelor's and Master's degree in Agronomy from the Department of Agronomy, Faculty of Agriculture, Kasetsart University, Thailand in 1995 and 2002, respectively. He graduated $\mathrm{PhD}$ in Science of Resources and Environment, United Graduate School of Agricultural Science, Tokyo University of Agriculture and Technology, Japan in 2009.

$\mathrm{He}$ is a lecturer in Agronomy Department, Faculty of Agriculture at Kamphaeng Saen, Kasersart University Kamphaeng Saen Campus, Thailand. His teaches in the field of Plant Climate, Water Management for Field Crops, Physiological of Field Crop Production, Advance Physiological of Field Crop Production and Crop Microclimate.

His research interests are prediction of weather and climate changes, global warning and agriculture, greenhouse gases emission and it's mitigation, gas flux measurement, plant stress by heat and drought and air pollutions.

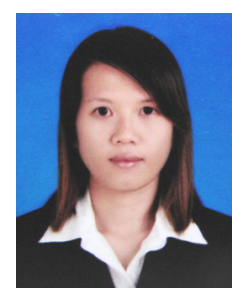

Nongpat Chaichana was born in Thailand. She graduated in Bachelor's of Science (Agriculture) majoring in Agronomy in 2003. Now she is studying for M.S. degree at Department of Agronomy, Faculty of Agriculture at Kamphaeng Saen, Kasetsart University. She interested in research in global climate changes, global warming, greenhouse gas monitoring and warning system for agricultural risk.

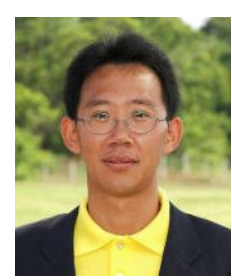

Jessada Phattaralerphong was born in Thailand. He was awarded his bachelor degree in Agriculture First Class Honors from the Department of Horticulture, Faculty of Agriculture, Kasetsart University. His Master's degree in Agriculture from Kasetsart University. He graduated Ph.D in Botany from Kasetsart University, and Dr. (Physiologie Genetique Moleculaires) from Universite Clermont-Ferrand-II, France. In 2004-2005, he work ing to Development of photograph technique to estimate geometrical parameters of isolated tree. U.M.R. PIAF, Institut Nationale de la Recherche Agronomique (INRA), France.

Now, he is a lecturer in Faculty of Natural Resources and Agro-Industry, Kasetsart University Chalermphrakiat Sakonnakhon Province Campus. His research interests lie in plant architecture, plant physiology light, microclimate and gas flux measurement.

Jate Sathornkich was born in Thailand. He graduated Bachelor of Science (Plant Science) Mahidol University in 1999. He awarded his Master's degree in Botany and Doctor's degree in Tropical Agriculture from Kasetsart University in 2002 and 2008, respectively. He is now a researcher at Department of Horticulture, Faculty of Agriculture, Kasetsart University. He is a researcher with expertise in canopy structure, $\mathrm{CO}_{2}$ flux, plant architecture, plant physiology light and hemispherical photograph. 